\title{
Judicial Negligence at the ICTY and the Liability of the Aider and Abettor*
}

\author{
BY ESZTER KIRs**
}

\begin{abstract}
The acquittal of Momčilo Perišić (former Chief of the Yugoslav Army General Staff, right hand of Slobodan Milošević during the Balkan wars) received a loud echo both in the affected countries and in the international media in 2013. His acquittal was based on an Appeal Judgement including an unconvincing interpretation of aiding and abetting liability. The author of the present paper discusses the judicial reasoning provided by the Appeals Chambers of the ICTY before the Perišić Appeal Judgement was delivered and demonstrates how negligence of judicial chambers can build case law which leaves the door wide open to highly debatable judicial conclusions. The paper briefly presents the 14-year story of the application of the concept of aiding and abetting liability by the ICTY Appeals Chambers, from the 2000 Aleksovski Appeal Judgement to the 2014 Sainović Judgement.

Keywords: international criminal law, aiding and abetting, ICTY, accessory liability
\end{abstract}

\section{PROLOGUE - CONTOURS OF THE CONCEPT OF AIDING AND ABETTING DRAWN BY THE FURUNDŽIJA TRIAL CHAMBER}

The contours of the liability concept of aiding and abetting was first drawn at the International Criminal Tribunal for the former Yugoslavia (hereinafter, ICTY) by the Trial Chamber in the case of Anto Furundžija. The reasoning of the Trial Judgement delivered in 1998 was based on in-depth analysis of post-World War II cases. The Trial Chamber needed to decide upon the issue of whether the presence of the accused, who was a local commander of the "Jokers", a unit of the Croatian Defence Council, at the interrogations and torture of the victims and through that his moral support and encouragement was sufficient to constitute the actus reus of aiding and abetting.

Based on the British case of Schonfeld, the Trial Chamber held that in giving additional confidence to his companions the defendant facilitated the commission of the crime. ${ }^{1}$ In the Rohde case, the Chamber found that actual presence at the crime was not necessary to be "concerned in the killing" as long as the defendant reassures the perpetrators and facilitates the commission of the crime in some significant way. ${ }^{2}$ Having analysed the Akayesu, the Dachau Concentration Camp and the Auschwitz Concentration Camp cases, the Trial Chamber drew its conclusion with regard to the evaluation of the physical presence of the defendant at the crime scene and the issue of silent approval. The defendants in the foregoing cases not solely lent moral support or encouragement to the perpetrators of the crime, but they also held some kind of authority (Akayesu as mayor of the commune where the atrocities occurred) or roles in the management of the concentration camps. Accordingly,

1 Prosecutor v Furundžija Case no IT-95-17/1-T (ICTY, 10 December 1998) para 202.

2 Prosecutor v Furundžija Case no IT-95-17/1-T (ICTY, 10 December 1998) paras 203-204.

* The paper was prepared in the framework of a research project supported by the OTKA (Hungarian Scientific Research Fund, PD 105832).

** Adjunct professor, Department of International Law, Faculty of Law, University of Miskolc. E-mail: kirs.eszter@gmail.com 
the Trial Chamber held based on the foregoing cases that the nature of the assistance provided by the aider and abettor can be psychological support of the perpetrator coupled with some form of authority.

As regards the effect of the assistance provided by the aider and abettor on the act of the principal perpetrator, the Trial Chamber discussed additional post-World War II cases, such as the Einsatzgruppen, the Zyklon B and the S. et al. ("Hechingen Deportation") cases. Based on the assessment of the respective judgements, the Trial Chamber came to the conclusion that without substantial influence on the commission of the crime, mens rea alone is not sufficient ground for a criminal conviction. It is essential for criminal liability under the concept of aiding and abetting that the assistance provided to the perpetrator has a substantial effect on the commission of the criminal offence. ${ }^{3}$

Following the 11-page long analysis of the case-law, the judgement provides a summary and discussion of the relevant international instruments. Article 2(3)(d) of the Draft Code of Crimes Against the Peace and Security of Mankind adopted in 1996 by the International Law Commission provided that the individual who "knowingly aids, abets or otherwise assists, directly and substantially, in the commission of [...] a crime, including providing the means for its commission" shall be held criminally responsible as an aider and abettor. ${ }^{4}$ The Trial Chamber added with regard to assisting ex post facto and based on the relevant Commentary of the International Law Commission, that "willingness to provide assistance, when made known to the perpetrator, would also suffice, if the offer or help in fact encouraged or facilitated the commission of the crime by the main perpetrator". 5 The Chamber emphasized that the ILC Commentary mentions that the assistance of the aider and abettor facilitates the commission of the crime "in some significant way". Consequently, the Chamber held that the assistance need not be a conditio sine qua non of the crime, however, the wording of the ILC clearly excludes cases of marginal participation. ${ }^{6}$

Based on the above considerations, the Trial Chamber drew the final conclusion that none of the cases which were discussed suggested that the acts of the accomplice need to be in a causal relationship with the criminal offence committed by the principal perpetrator. The actus reus of aiding and abetting in international criminal law requires practical assistance, encouragement, or moral support, which has a substantial effect on the perpetration of the crime. ${ }^{?}$

\section{A "LANDMINE" PLANTED BY THE TADIĆ APPEALS CHAMBER}

In 1999, the Tadić Appeals Chamber created a brand new concept for co-perpetration, namely the Joint Criminal Enterprise (hereinafter, JCE) as a result of extensive judicial activism. While setting up the elements of the definition of this controversial and broadly criticized concept, the Chamber also made a comparison between the concept of JCE and that of aiding and abetting. The Chamber identified the following distinctive features:

3 Prosecutor v Furundžija Case no IT-95-17/1-T (ICTY, 10 December 1998) paras 217-224.

4 Report of the ILC, on the work of its forty-eighth session G.A. Supp. No. 10 (A/51/10) 1996, 18.

5 Prosecutor v Furundžija Case no IT-95-17/1-T (ICTY, 10 December 1998) para 230.

6 Prosecutor v Furundžija Case no IT-95-17/1-T (ICTY, 10 December 1998) para 231.

7 Prosecutor v Furundžija Case no IT-95-17/1-T (ICTY, 10 December 1998) paras 233-235. 
(i) The aider and abettor is always an accessory to a crime perpetrated by another person, the principal.

(ii) In the case of aiding and abetting no proof is required of the existence of a common concerted plan, let alone of the pre-existence of such a plan. No plan or agreement is required: indeed, the principal may not even know about the accomplice's contribution.

(iii) The aider and abettor carries out acts specifically directed to assist, encourage or lend moral support to the perpetration of a certain specific crime $[\ldots]$, and this support has a substantial effect upon the perpetration of the crime. [...]

(iv) In the case of aiding and abetting, the requisite mental element is knowledge that the acts performed by the aider and abettor assist the commission of a specific crime by the principal. ${ }^{8}$

This definition of the Appeals Chamber on the actus reus of aiding and abetting is identical with the one applied by the Furundžija Trial Chamber in the elements of (1) assistance, moral support or encouragement, and (2) its substantial effect upon the perpetration of the crime. At the same time, and without in-depth or any kind of legal analysis and failing to assess the existing norms of customary international law, the Appeals Chamber added in some kind of negligent style that the acts of the aider and abettor shall be specifically directed to assist the commission of a certain specific crime. Even though, as seen under paragraph (iv), the Chamber applied the mens rea standard rooted in customary international law, it arbitrarily and without any underlining or convincing reasoning implicitly (while discussing actus reus) lifted the mens rea threshold for aiding and abetting liability.

This negligent act of the Chamber of creating a new standard through judicial lawmaking did not have a direct and significant impact on the case in question, since the accused Tadić, the former President of the Local Board of the Serb Democratic Party in Kozarac, directly participated in the commission of murder, torture and inhuman treatment, and the collection and forced transfer of civilians to detention camps, where they were held in unlawful confinement. For his conviction, the application of the concept of aiding and abetting was not required. Accordingly, without any urgent need for applying the concept, the Appeals Chamber modified its definition with the sole purpose of crystallizing the newly created JCE concept through distinction from other forms of liability. By this act, the Tadic Appeals Chamber planted a "landmine" in the field of future jurisdiction.

\section{APPEALS CHAMBER FAILING TO DEACTIVATE THE "LANDMINE": FROM THE ALEKSOVSKI TO THE LUKIĆ CASE}

The Appeals Chamber had 13 years to deactivate the "landmine" planted by the Tadić Appeal Judgement in 1999 before it exploded. The Chamber failed to do so. The repetitive citation of the definition set by the Furundžija was justifiable until 2004 to a certain extent, even though further and deeper analysis of customary international law and preceding judicial bodies conducted by the Appeals Chamber could have enhanced the finding of the Furundžija Trial Chamber. Accordingly, the 13 years of passivity can be divided into two sections: (1) until the 2004 Vasiljević Appeal Judgement, when the Furundžija standards

8 Prosecutor v Tadić Case no IT-94-1-A (ICTY, 15 July 1999) para 229. 
were applied in all Appeal procedure, and (2) the second section following 2004, when the Tadić "specifically directed" requirement was approved by another Appeals Chamber.

From the first period, two relevant judgements delivered by the Appeals Chamber need to be mentioned. These are the Aleksovski Appeal Judgement and the Čelebići Appeal Judgement delivered in 2000 and 2001. In both cases, the Appeals Chamber approved the finding and reasoning of the Furundžija Trial Chamber. In accordance with this approach, the Aleksovski Appeal Chamber pointed out that "what must be shown is that the aider and abettor was aware of the essential elements of the crime which was ultimately committed by the principal". 9 Although the Chamber failed to extend the research and assessment of customary international law done by the Furundžija Trial Chamber, it explicitly discussed the wording of the Tadic Appeals Chamber with regard to aiding and abetting, and made the following significant statement: "in the Tadic Judgement, the Appeals Chamber briefly considered the liability of one person for the acts of another person where the first person has been charged with aiding and abetting that other person in the commission of the crime. This was in the context of contrasting that liability with the liability of a person charged with acting pursuant to a common purpose or design with another person to commit a crime, and for that reason that judgement does not purport to be a complete statement of the liability of the person charged with aiding and abetting." 10 By this holding, the Aleksovski Appeals Chamber distanced itself from the wording of the Tadić Appeals Chamber, even if it failed to go into more detailed discussion on the issue of why the unjustified element added to the definition cannot be accepted, and what kind of risks it might lead to in the assessment of the liability of future accused.

The Appeals Chamber in the "Čelebići Camp" case had to focus on another aspect of the application of the concept of aiding and abetting due to the fact that the defence of Appellant Delalić raised the argument in their Appeal Brief that the indictment did not charge him with aiding and abetting but instead used the word "participation" for his liability. Therefore, the Appeals Chamber was called to explain in detail why the concept of aiding and abetting can fit into the broader notion of "participation". The Chamber put so little emphasis on the issue of the definition of the concept, that it referred to the Tadic Appeals Judgement as one which would underpin the definition applied by the Trial Chamber (following the Furundžija standard), and as such, it failed to point out the mistaken interpretation of the concept provided by the Tadic Appeals Chamber. It simply ignored the problematic part of the Tadić definition. ${ }^{11}$

The Vasiljević Appeal Judgement delivered in 2004 can be interpreted as a turning point in the process of assessing aiding and abetting by the Appeals Chamber of the ICTY. Until then, the Tadic definition had not entered the findings of the Appeals Chamber in other cases. Just like in the above presented cases, the Vasiljević Appeals Chamber did not provide any in-depth analysis on the issue, referred to the Tadic Appeals Judgement in order to underpin the classical actus reus requirement of the "substantial effect upon the perpetration of the crime", and then, without any detailed explanation, it held that "the acts of the Appellant were specifically directed to assist the perpetration of the murders and the inhumane acts and his support had a substantial effect upon the perpetration of the crimes". ${ }^{12}$ This unnecessary verbatim citation of the Tadic Appeals Judgement including the

\footnotetext{
9 Prosecutor v Aleksovski Case no IT-95-14/1-A (ICTY, 24 March 2000) para 162 (ii).

10 Prosecutor v Aleksovski Case no IT-95-14/1-A (ICTY, 24 March 2000) para 163.

1 Prosecutor v Mucić et al. Case no IT-96-21-A (ICTY, 20 February 2001) para 352.

12 Prosecutor v Vasiljević Case no IT-98-32-A (ICTY, 25 February 2004) para 135.
} 
mistaken "specifically directed" element was just like stepping on the mine field, detecting the landmine but instead of deactivating it, just ignorantly passing by.

In the specific case, this failure did not have a great significance, since the facts of the case clearly demonstrated a strong basis for conviction under the concept of aiding and abetting. Vasiljević, member of the Bosnian Serb paramilitary unit, the "White Eagles", held seven Muslim men at the Vilina Vlas Hotel in Višegrad and walked with them to the Drina River, pointed his gun at them shortly before they were shot by the principal perpetrators. These acts of the defendant provided a solid ground even for the application of the "specifically directed" judge-made requirement, and did not demand the thorough analysis of the actual legal basis of the concept. At the same time, adapting a criterion which was rejected earlier by the Aleksovski Appeals Chamber expressis verbis, and failing to come up with a detailed reasoning underpinning this standpoint, can be seen as a serious gap in the judicial reasoning. From this time on, whenever the Appeals Chamber applied the form of liability of aiding and abetting, it had to face conflicting previous decisions, and therefore, it was obliged to determine which decision it would follow, or whether it would depart from both conflicting decisions for cogent reasons in the interests of justice. ${ }^{13}$

Since the defendant Jokic submitted the argument with regard to the legal element of actus reus of aiding and abetting that the practical assistance given to the perpetrators, in addition to having substantial effect on the commission of the crime, must be specifically directed to this end, the Appeals Chamber had to discuss the issue of the Tadic criteria in the Blagojević et al. case in more detail. The Appeal Judgement of 2007 includes the same conclusion as the one previously drawn by the Aleksovski Appeals Chamber, namely, that the statement at issue to be found in the Tadic Appeal Judgement "followed a discussion of the mens rea and actus reus of joint criminal enterprise liability and was introduced for the purpose of distinguishing aiding and abetting from acting in pursuance of a common purpose or design to commit a crime, the latter requiring only that the participant perform acts that are "in some way directed" to the furtherance of the common plan or purpose." 14 The Chamber assessed the preceding relevant case-law of the ICTY. It emphasized that the Appeals Chamber had already assessed in the Blaškić case whether the actus reus of aiding and abetting requires a causal link between the act of the accused and the act of the principal perpetrator and found that it was not required. In addition, it considered the findings of the Appeals Chamber in the Vasiljević and the Čelebići cases, ${ }^{15}$ but failed to make an in-depth analysis to finally give a detailed and convincing answer to the question of why the Furundžija standard should be followed in any cases of aiding and abetting.

The Appeals Chamber failed to deactivate the "landmine" also in the Mrkšić and the Lukić cases. Both Appeal Judgements (delivered in 2009 and 2012) reject the requirement of "specific direction" but none of them demonstrates a deeper analysis of precedents of international criminal law or customary international law. In the Mrkšić case, the Appeals Chamber simply reiterated that "it is not necessary that the aider and abettor knows the precise crime that was intended and was in fact committed, if he is aware that one of a number of crimes will probably be committed, and one of those crimes is committed, he has intended to facilitate the commission of that crime, and is guilty as an aider and abettor." 16 Therefore, one can see it as an exaggeration when the Appeals Chamber

13 Prosecutor v Aleksovski Case no IT-95-14/1-A (ICTY, 24 March 2000) para 111.

14 Prosecutorv Blagojević\&Jokić Case no IT-02-60-A (ICTY, 9 May 2007) para 185.

15 Prosecutor v Blagojević\&Jokić Case no IT-02-60-A (ICTY, 9 May 2007) paras 184-191.

16 Prosecutor v Mrkšić\&Šljivančanin Case no IT-95-13/1-A (ICTY, 5 May 2009) para 159. 
concluded in the Lukić \& Lukić case that in the Mrkšić case the Appeals Chamber "has clarified (sic!) that 'specific direction' is not an essential ingredient of the actus reus of aiding and abetting and finds that there is no 'cogent reason' to depart from this jurisprudence" ${ }^{17}$ How could the Appeals Chamber possibly come to such a conclusion without in-depth analysis and thorough assessment of customary international law?

\section{EXPLOSION OF THE "LANDMINE": THE PERIŠIĆ CASE}

Momčilo Perišić served as Chief of the Yugoslav Army General Staff from 1993 to 1995. The Yugoslav Army provided logistical assistance to the Army of the Republika Srpska (hereinafter, RS), including the supply of weapons, ammunition, personnel to whom the Yugoslav Army provided salaries. The war strategy in Sarajevo and Srebrenica led to the systematic perpetration of the well-known, horrific atrocities against civilians. Perišić was informed about the acts of violence against Bosnian Muslims perpetrated in Bosnia and Herzegovina and that his actions provided practical assistance to the perpetrators of these crimes.

The judgment in his case was highly significant also due to the fact that no high-level political or military stakeholder of the Yugoslav Army and Serbia has been convicted by the ICTY for war crimes committed on the territory of Bosnia.

In September 2011 the Trial Chamber found Perišić guilty as an aider and abettor of murder, inhumane acts and persecution as crimes against humanity and violations of laws and customs of war committed in Sarajevo, Srebrenica and Zagreb. He was sentenced to 27 years imprisonment. ${ }^{18}$

The Appeals Chamber found an error of law in the reasoning of the Trial Chamber, namely that the Trial Chamber stated that the element of "specific direction" is not needed for the actus reus of aiding and abetting. The Appeals Chamber arrived to a contrary conclusion maintaining that it must be proven that the assistance provided by the accused was specifically directed to facilitate the commission of the specific crimes. ${ }^{19}$

The Appeals Chamber held that it was "not persuaded that [the] Mrkšić [...] Appeal judgment reflected an intention to depart from the settled precedent established by the Tadic Appeal judgment. ${ }^{\circ 20}$ In addition, the Chamber emphasized that if the aider/abettor was not present at the commission of the crime and remote from the relevant crime an explicit consideration of specific direction is required. Thereafter, without going into deeper analysis of the concept and customary international law on aiding and abetting, and solely relying automatically on the Tadic judgment, the Chamber concluded that specific direction could not be proven beyond reasonable doubt. The Army of RS was not a criminal organization per se. It was an army fighting war. Assistance provided to the army's general war efforts does not, in itself, demonstrate that assistance facilitated by Perišić was specifically directed to aid the crimes committed by members of the Army of RS. ${ }^{21}$

The Appeals Chamber, therefore, acquitted Perišić on all counts of the indictment. The judgment of the Chamber is far from convincing. Contrary to its reasoning and as presented above, preceding judicial chambers on the concept of aiding and abetting pointed out that

17 Prosecutor v Lukić\&Lukić Case no IT-98-32/1-A (ICTY, 4 December 2012) para 424.

18 Prosecutor v Perišić Case no IT-04-81-T (ICTY, 6 September 2011)

19 Prosecutor v Perišić Case no IT-04-81-A (ICTY, 28 February 2013) paras 13-74.

20 Prosecutor v Perišić Case no IT-04-81-A (ICTY, 28 February 2013) para 32.

21 Prosecutor v Perišić Case no IT-04-81-A (ICTY, 28 February 2013) paras 25-69. 
knowledge about the specific crimes is sufficient to maintain the mens rea element. It must be proven that the accused was aware of the fact that the principal perpetrator used the assistance provided by the accused for the purpose of engaging in criminal conduct. ${ }^{22}$ Knowledge has been required about the fact that the assistance provided support to the perpetrator to commit the crimes. By insisting on the requirement of the "specific direction", the Appeals Chamber raised the threshold for the mens rea element of aiding and abetting liability. This undermines the purpose of the whole concept, namely, to facilitate criminal accountability of those responsible for knowingly facilitating the commission of international crimes (obviously resulting in lesser sentences than in the case of perpetrators such as members of a JCE).

The systematic and widespread sniping and shelling of civilians in Sarajevo in the period of over 3 years made it obvious that the Army of the RS relied on criminal acts to further its siege. It was proven beyond reasonable doubt that Perišić provided significant logistical assistance to this Army and had the power to approve or deny aid requests from the Army of RS. Without this aid, the Army of RS could not have operated effectively as an army. Therefore, the assistance provided by Perišić had a substantial effect on the crimes perpetrated by the Army of RS in Sarajevo and Srebrenica. Perišić was informed from a variety of sources about the criminal conduct of the Army of RS (not only through diplomatic channels, since the atrocities had a wide media coverage), and he nonetheless continued to provide support. In spite of all the foregoing circumstances, he was acquitted based on the requirement of "specific direction" introduced by the Tadić Appeal Chamber. The "landmine" exploded due to the fact that a number of judicial chambers had failed to take the effort to deactivate it.

Table 1. Summary of the discussed judgements concerning "specific direction"

\begin{tabular}{|l|l|}
\hline “Specific Direction” Required & "Specific Direction” NOT Required \\
\hline Tadić AJ (1999) & Furundžija TJ (1998) \\
\hline & \\
\hline & Aleksovski AJ (2000) \\
\hline Vasiljević AJ (2004) & Čelebići AJ (2001) \\
\hline & \\
\hline & Blagojević AJ (2007) \\
\hline & Mrkšić AJ (2009) \\
\hline Perišić AJ (2013) & Lukić AJ (2012) \\
\hline & \\
\hline
\end{tabular}

22 See Prosecutor v Perišić Case no IT-04-81-A (ICTY, 28 February 2013), Partially dissenting opinion of Judge Liu. 
Table 2. Members of the judicial chambers

\begin{tabular}{|l|l|}
\hline Furundžija TC & Florence Ndepele Mwachande Mumba (presiding), Antonio Cassese, Richard May \\
\hline Tadić AC & $\begin{array}{l}\text { Mohamed Shahabuddeen (presiding), Antonio Cassese, Wang Tieya, } \\
\text { Rafael Nieto-Navia, Florence Mumba }\end{array}$ \\
\hline Aleksovski AC & $\begin{array}{l}\text { Richard May (presiding), Florence Mumba, David Hunt, Wang Tieya, } \\
\text { Patrick Robinson }\end{array}$ \\
\hline Čelebići AC & $\begin{array}{l}\text { David Hunt (presiding), Fouad Riad, Rafael Nieto-Navia, Mohamed Bennouna, } \\
\text { FaustoPocar }\end{array}$ \\
\hline Vasiljević AC & $\begin{array}{l}\text { Theodor Meron (presiding), Wolfgang Schomburg, Mohamed Shahabuddeen, } \\
\text { Mehmet Güney, Inés Mónica }\end{array}$ \\
\hline Blagojević AC & $\begin{array}{l}\text { Fausto Pocar (presiding), Mohamed Shahabuddeen, Mehmet Güney, AndrésiaVaz, } \\
\text { Theodor Meron }\end{array}$ \\
\hline Mrkšić AC & Theodor Meron (presiding), Mehmet Güney, FaustoPocar, Liu Daqun, AndrésiaVaz \\
\hline Lukić AC & $\begin{array}{l}\text { Mehmet Güney (presiding), FaustoPocar, Liu Daqun, Carmel Agius, } \\
\text { Howard Morrison }\end{array}$ \\
\hline Perišić AC & $\begin{array}{l}\text { Theodor Meron (presiding), Carmel Agius, Liu Daqun (dissenting), AndrésiaVaz, } \\
\text { Arlette Ramaroson }\end{array}$ \\
\hline Sainović AC & $\begin{array}{l}\text { Liu Daqun (presiding), Mehmet Güney, Fausto Pocar, Arlette Ramaroson, } \\
\text { Bakhtiyar Tuzmukhamedov }\end{array}$ \\
\hline
\end{tabular}

\section{EPILOGUE - CLARIFICATION OF THE CONCEPT PROVIDED BY THE SAINOVIĆ APPEALS CHAMBER}

The acquittal of Perišić received great exposure in both the affected countries and the international media. The intense reaction of the society, apart from the interests of justice, provided another pressing need for the clarification of the concept. The community of experts and lay persons who kept an eye on the fate of the harmful "specific direction" theory did not need to wait for long until a case appeared where the concept of aiding and abetting had to be applied. The Appeals Chamber (with Judge Liu Daqun presiding who was also a member of the Perišić Appeals Chamber, and attached a dissenting opinion to that judgement) took the opportunity to clarify once and for all for the ICTY jurisdiction what existing customary international law says about the liability of an aider and abettor. It emphasized in its judgement delivered in 2014 in the Sainović case, as a starting point of its analysis of the relevant case-law of the ICTY, that primary consideration should be given to positions expressly taken and clearly set out in the judgements concerned. ${ }^{23}$ It clearly rejected the opinion of the majority of the Perišić Appeals Chamber, and concluded that the requirement of substantial contribution had been the consistent element of the actus reus of aiding and abetting and correctly found that even though the Furundžija Trial Judgement elicited the definition from an analysis of customary international law, there was nonetheless a need for the re-examination of customary international law in order to dispel any doubt with regard to the elements of aiding and abetting. ${ }^{24}$ It not only extended the analysis provided by the Furundžija Trial Chamber on post-World War II cases, but also assessed the

23 Prosecutor v Sainović et al. Case no IT-05-87-A (ICTY,23 January 2014) para 1621.

24 Prosecutor v Sainović et al. Case no IT-05-87-A (ICTY,23 January 2014) paras 1618-1626. 
question of whether domestic laws of the major legal systems of the world accept and adopt the same approach to the potential "specific direction" element of aiding and abetting liability. It elaborated upon the national legal framework applicable in a broad range of countries, such as Mexico, India, Indonesia, New Zealand, Australia, South Africa, France, Belgium, Algeria, Morocco, Burundi, Germany, China, Bulgaria, Canada, the United Kingdom, the United States, etc., and came to the final conclusion that requiring of "specific direction" has never been a general, uniform practice in national jurisdictions. ${ }^{25}$ The Appeals Chamber, thereby, excluded the possibility of future ICTY judicial chambers reactivating a "landmine" similar to the one planted by the Tadić Appeals Chamber. Any judge who nonetheless tries to do so aiming for the extension of the actus reus of aiding and abetting, should be prepared to demonstrate a detailed and convincing reasoning as opposed to the Sainović Appeal Judgement, which provides a clear and thorough analysis of customary international law.

25 Prosecutor v Sainović et al. Case no IT-05-87-A (ICTY,23 January 2014) paras 1643-1646. 